\title{
Comparative Evaluation of Alternative Forages to Grass Silage in the Diet of Early Lactation Dairy Cows
}

\author{
F. Burke, ${ }^{\star} †$ J. J. Murphy, ${ }^{\star 1}$ M. A. O’Donovan, ${ }^{\star}$ F. P. O’Mara,† S. Kavanagh,‡ and F. J. Mulligan† \\ *Teagasc Moorepark Dairy Production Research Centre, Fermoy, Co. Cork, Ireland \\ †School of Agriculture, Food Science and Veterinary Medicine, University College Dublin, Belfield, Dublin 4, Ireland \\ $\ddagger$ Teagasc, Kildalton College, Piltown, Co. Kilkenny, Ireland
}

\section{ABSTRACT}

Fifty-six autumn-calving Holstein-Friesian cows, blocked on the basis of days in milk $(27.6 \pm 10.65 \mathrm{~d})$, lactation number $(3.1 \pm 2.21)$, and preexperimental milk yield $(28.4 \pm 6.69 \mathrm{~kg})$ were used to examine the effects of replacing $330 \mathrm{~g} / \mathrm{kg}$ of dry matter (DM) of firstcut perennial ryegrass silage with either fermented whole-crop wheat (WCW), urea-treated processed WCW, or corn silage on subsequent feed intake, milk production, and efficiency of nitrogen utilization. The $\mathrm{DM}(\mathrm{g} / \mathrm{kg})$, crude protein $(\mathrm{CP}, \mathrm{g} / \mathrm{kg}$ of $\mathrm{DM})$ and in vitro $\mathrm{DM}$ digestibility $(\mathrm{g} / \mathrm{kg})$ of the forages were 204,179 , and 762 for grass silage; 389, 90, and 711 for fermented WCW; 795, 141, and 768 for urea-treated processed WCW; and 346, 93, and 783 for corn silage, respectively. Four forage treatments were evaluated as follows: 1) grass silage as the sole forage (GS); 2) a mixture of grass silage and fermented WCW silage, (F-WCW); 3) a mixture of grass silage and urea-treated processed WCW, (UP-WCW); and 4) a mixture of grass silage and corn silage (CS). In all cases, the alternative forages comprised $67 \%$ of the forage mix on a DM basis. Isonitrogenous diets were formulated by offering all cows 8 $\mathrm{kg}$ of concentrate as fed, formulated to different $\mathrm{CP}$ concentrations. Cows were offered these diets from 28 to $104 \mathrm{~d}$ in milk. Total DM intake and milk yield were greater on UP-WCW (20.0 and $30.2 \mathrm{~kg} / \mathrm{d})$ and CS (18.3 and $33.2 \mathrm{~kg} / \mathrm{d}$ ) than on GS (13.5 and $26.5 \mathrm{~kg} / \mathrm{d})$. Although DM intake was greater on F-WCW $(17.1 \mathrm{~kg} / \mathrm{d})$ than on GS, milk yield was not significantly greater $(+2.7 \mathrm{~kg} / \mathrm{d})$. Milk protein concentration was greater on F-WCW (30.5 g/kg), UP-WCW (31.3 g/kg), and CS (30.7 $\mathrm{g} / \mathrm{kg})$ than on GS $(28.5 \mathrm{~g} / \mathrm{kg})$. However, there was no difference between treatments in milk fat or lactose concentrations. Body weight change was greater for cows offered GS $(-0.27 \mathrm{~kg} / \mathrm{d})$ than for those offered UPWCW $(-0.01 \mathrm{~kg} / \mathrm{d})$ and CS $(+0.05 \mathrm{~kg} / \mathrm{d})$ but not compared with those offered F-WCW $(-0.06 \mathrm{~kg} / \mathrm{d})$. There was no

Received May 27, 2006.

Accepted September 15, 2006

${ }^{1}$ Corresponding author. john.murphy@teagasc.ie effect of treatment on plasma glucose, nonesterified fatty acids, $\beta$-hydroxybutyrate, urea, or total protein at d $64 \pm 17.4$ and d $92 \pm 17.4$ postpartum. Efficiency of $\mathrm{N}$ utilization was greatest for $\mathrm{CS}$ with 0.36 of $\mathrm{N}$ intake being recovered in milk compared with $0.28,0.32$, and 0.26 for GS, F-WCW, and UP-WCW, respectively. There was no effect of treatment on milk urea $\mathrm{N}$ concentration or the urinary allantoin $\mathrm{N}$ to creatinine $\mathrm{N}$ ratio. The results of this experiment indicate that corn silage is a more suitable supplementary forage to grass silage than fermented or urea-treated processed WCW, with advantages realized in milk production and more efficient $\mathrm{N}$ utilization.

Key words: alternative forage, dairy cow, milk production, nitrogen utilization

\section{INTRODUCTION}

Grass silage is the predominant winter forage for dairy cattle in Ireland and in many other parts of northern Europe. However, grass silage is extremely variable in terms of feeding value and preservation quality and many reports indicate that supplementing grass silage with other forages improves dairy cow performance (O'Mara et al., 1998). In particular, grass silage tends to have a relatively low DMI potential, which reduces its usefulness in the diets of high-producing dairy cattle.

There are relatively few alternative forages available for dairy cattle in northern Europe. Advances in plant breeding and husbandry methods have meant that the use of corn silage for feeding dairy cattle has increased in northern Europe in recent years. Previous studies have shown greater DMI, milk production, and milk protein concentration with corn silage-based diets when compared with grass silage-based diets (Phipps et al., 1995; O’Mara et al., 1998). Whole-crop cereals (barley and wheat) have been used as alternatives to grass silage in dairy cattle diets (Abdalla et al., 1999; Sutton et al., 2001), and can be preserved as either fermented (harvested at 350 to $450 \mathrm{~g} / \mathrm{kg} \mathrm{DM}$ ) or urea-treated (harvested at $>550 \mathrm{~g} / \mathrm{kg}$ of DM) forage. Two forms of wholecrop wheat (WCW) were used in this experiment. One was a conventional fermented WCW and the other was 
a novel form of urea-treated WCW, which was processed at harvesting by a roller mill installed in the harvester, and cut at a higher straw stubble height than for previous experiments. With the exception of reports by Murphy et al. (2004) and Sinclair et al. (2005), there are no data in the literature on the nutritive value of ureatreated processed WCW. Murphy et al. (2004) found no difference in cow performance between the fermented and urea-treated processed WCW despite greater intake on the urea-treated processed WCW diet. Both were harvested at the same stubble height. In an attempt to improve the performance of the urea-treated processed WCW, a greater stubble length was left after harvesting to reduce the amount of lignified straw in this feed and increase its starch content. The objective of the current study was to evaluate the replacement of grass silage with fermented WCW, a novel form of urea-treated processed WCW and corn silage, specifically with respect to DMI, milk production, milk composition and nitrogen utilization in dairy cows.

\section{MATERIALS AND METHODS}

This experiment was conducted at Moorepark Research Centre, Fermoy, Co. Cork, Ireland, $\left(55^{\circ} 10^{\prime} \mathrm{N}\right.$, $\left.8^{\circ} 16^{\prime} \mathrm{W}\right)$. Animals were housed in a free-stall barn fitted with rubber mats, bedded with sawdust twice daily with the loafing area scraped every $2 \mathrm{~h}$. All animals had continuous access to water.

\section{Treatments, Experimental Design, and Animals}

Fifty-six Holstein-Friesian dairy cows were blocked into groups of 4 on the basis of milk yield, DIM, and parity (multiparous or primiparous). Thirty-six cows were multiparous, and the remaining 20 were primiparous. Cows were assigned at random from within blocks to the following 4 forage treatments: 1) grass silage as the sole forage (GS); 2) a mixture of grass silage and fermented WCW silage (F-WCW); 3) a mixture of grass silage and urea-treated processed WCW (UP-WCW); and 4) a mixture of grass silage and corn silage (CS). In all cases, the alternative forages comprised $67 \%$ of the forage mix on a DM basis. As the cows calved over approximately a 7 -wk period, this blocking procedure was applied to batches of animals on 3 separate occasions in 2004: October $26(\mathrm{n}=32)$, November $8(\mathrm{n}=$ $12)$, and November $15(\mathrm{n}=12)$.

Average BW and BCS were similar for all treatments at the beginning of the experiment $(593 \pm 73$ and $3.30 \pm$ 0.5 , respectively). Cows were housed immediately after calving and were trained to use an individually recorded electronic feeding system (Griffith Elder and Company Ltd., Bury St. Edmunds, Suffolk, UK). The preexperimental diet consisted of a 50:50 grass silage:corn silage mixture plus $8 \mathrm{~kg}$ of a $250 \mathrm{~g} / \mathrm{kg} \mathrm{CP}$ concentrate, which was fed from calving until assignment to treatment $(27.6 \pm 10.65$ DIM). Regardless of when cows were assigned to treatments, the experimental period was $11 \mathrm{wk}$, with the first week used as an adaptation period and data from wk 2 to 11 used to compare treatments. Cows were on trial between wk 4 and 15 of lactation approximately. At the start of the experiment, mean milk yield was $28.4 \pm 6.69 \mathrm{~kg} / \mathrm{d}$, lactation number was $3.1 \pm 2.21$, and DIM were $27.6 \pm$ $10.65 \mathrm{~d}$.

\section{Diets}

The grass silage was prepared without additive from the first cut of a predominantly perennial ryegrass sward (Lolium perenne), which was harvested on May 19, 2004. The fermented WCW and urea-treated processed WCW were prepared from a spring wheat variety (cv. Raffles). The fermented WCW was harvested at a DM content of $414 \mathrm{~g} / \mathrm{kg}$ on August 4, 2004, leaving a stubble height of approximately $20 \mathrm{~cm}$, and was ensiled in a walled silo without additive under plastic sheeting. The urea-treated processed WCW was harvested at a DM content of $750 \mathrm{~g} / \mathrm{kg}$ on August 27, 2004, leaving a stubble height of approximately $35 \mathrm{~cm}$. A greater stubble height was left after harvesting the urea-treated processed WCW to reduce the amount of lignified straw in this feed and thereby increase its starch content. The later cutting date was imposed to allow for greater maturity of the urea-treated processed WCW, which is the commercial recommendation for this form of WCW. It was ensiled in a walled silo, and the urea additive "Home 'n' Dry" alkaline preservative (Volac Ltd., Killeshandra, Co. Cavan, Ireland) was applied over each trailer load of the forage in the silo at a rate of $35 \mathrm{~g} /$ $\mathrm{kg}$. The corn silage (Zea mays) was of the Avenir variety, which was sown without a plastic cover (a plastic cover is sometimes used to increase the temperature of the soil in northern Europe). It was harvested at a DM content of $373 \mathrm{~g} / \mathrm{kg}$ on October 7, 2004, and ensiled without additive.

The forage mixtures were supplemented with $8 \mathrm{~kg}$ of concentrates per cow (as fed) of differing CP concentrations to maintain the CP concentration of the overall diet at approximately 160 to $170 \mathrm{~g} / \mathrm{kg}$ of DM. This was to supply isonitrogenous diets at the recommended level of CP as suggested by the National Research Council (NRC, 2001). The concentrates were formulated to give an as-fed CP concentration of $180 \mathrm{~g} / \mathrm{kg}$ for the GS treatment, $230 \mathrm{~g} / \mathrm{kg}$ for the UP-WCW treatment, $250 \mathrm{~g} / \mathrm{kg}$ for the F-WCW treatment, and $250 \mathrm{~g} / \mathrm{kg}$ for the CS treatment. The ingredients used were barley, corn glu- 
Table 1. Ingredients and composition of concentrates offered

\begin{tabular}{lccc}
\hline & \multicolumn{3}{c}{$\begin{array}{c}\text { Concentrate CP content } \\
\text { (as fed), g/kg }\end{array}$} \\
\cline { 2 - 4 } & 180 & 230 & 250 \\
\hline Ingredients, kg/t as fed & & & \\
Barley (rolled) & 250 & 180 & 160 \\
Corn gluten feed & 290 & 290 & 280 \\
Unmolassed sugar beet pulp & 240 & 180 & 160 \\
Soybean meal (480 g/kg CP) & 160 & 290 & 340 \\
Fat (vegetable) & 30 & 30 & 30 \\
Minerals and vitamins & 30 & 30 & 30 \\
Composition & & & \\
DM, g/kg & 874 & 877 & 876 \\
CP, g/kg of DM & 206 & 252 & 274 \\
NDF, g/kg of DM & 241 & 237 & 239 \\
Ash, g/kg of DM & 85 & 86 & 89 \\
Starch, g/kg of DM & 177 & 145 & 123 \\
Ether extract, g/kg of DM & 37 & 39 & 40 \\
DOMD, 1,2 g/kg of DM & 766 & 767 & 768 \\
PDIN, ${ }^{3}$ g/kg of DM & 142 & 178 & 193 \\
PDIE, g/kg of DM & 131 & 158 & 166 \\
ME, ${ }^{1}$ MJ/kg of DM & 12.3 & 12.3 & 12.3 \\
\hline
\end{tabular}

${ }^{1}$ Estimated based on Energy Allowances and Feeding Systems for Ruminants (MAFF, 1987).

${ }^{2}$ DOMD $=$ Digestible OM in the DM.

${ }^{3} \mathrm{PDIN}=$ True protein digested in the small intestine when fermentable $\mathrm{N}$ is limiting; PDIE = True protein digested in the small intestine when fermentable energy is limiting.

ten feed, sugar beet pulp (unmolassed), soybean meal $(48 \% \mathrm{CP})$, vegetable fat, and minerals and vitamins (Table 1).

The forages were mixed in a diet mixer wagon and were offered once daily after the morning milking and cows were allowed ad libitum access to the forages whereby approximately $10 \%$ of the quantity offered was unconsumed. All concentrates were offered in automatic feeders (Griffith Elder and Company Ltd.), which allowed animals to consume up to $4 \mathrm{~kg} / \mathrm{cow}$ in each 12 $\mathrm{h}$ period.

\section{Samples and Animal Measurements}

Forages were sampled twice weekly and concentrates were sampled once weekly (approximately 500-g samples) for determination of DM concentration and for chemical analysis. Forage samples were composited into 1 sample/wk to give 14 samples of each forage and concentrate for analysis. Separate samples of each forage were taken to obtain accurate forage DM and forage quality estimates and to avoid the potential risk of obtaining an unrepresentative sample of the mixed forages from the mixer wagon. The weight of each forage added to the diet mixer wagon was recorded every morning so that the DM concentration of the mixes could be accurately calculated.

The DMI of forages and concentrates was measured using an electronic feeding system (Griffith Elder and
Company Ltd.). Forage mangers were mounted on electronic load cells, and automatic feeders dispensed concentrate. The $\mathrm{N}$, true protein digested in the small intestine when fermentable $\mathrm{N}$ is limiting (PDIN), and true protein digested in the small intestine when fermentable energy is limiting (PDIE) intakes were calculated as the DMI of the forages and concentrates multiplied by the respective proportion of N, PDIN, and PDIE. The RDP balance for the respective treatments was calculated by subtracting the PDIE supply from the PDIN supply for each of the forage treatments. Metabolizable energy intakes were calculated as the DMI of the forages and concentrates multiplied by their respective $\mathrm{ME}$ concentrations. The $\mathrm{ME}$ concentrations in the forages were estimated using equation number 58 in Energy Allowances and Feeding Systems for Ruminants (Ministry of Agriculture, Fisheries and Food, 1987). The ME concentrations in the concentrates were estimated based on book values (Ministry of Agriculture, Fisheries and Food, 1987) for the ME concentration in the ingredients multiplied by the proportion of each ingredient in the concentrate. The ME for maintenance and BW change was calculated as described in Energy Allowances and Feeding Systems for Ruminants (Ministry of Agriculture, Fisheries and Food, 1987). The $\mathrm{ME}$ output required per kilogram of milk production was calculated using the equation of Tyrrell and Reid (1965): $\mathrm{ME}=0.0384 \times$ fat concentration in $\mathrm{g} / \mathrm{kg}+0.0223$ $\times$ protein concentration in $\mathrm{g} / \mathrm{kg}+0.0199 \times$ lactose concentration in $\mathrm{g} / \mathrm{kg}-0.108)$. The ME balance was calculated as the difference between ME intake and the sum of ME for maintenance, BW change, and milk output. Milk yield was recorded daily using electronic milk meters (DairyMaster, Causeway, Co. Kerry, Ireland). Milk composition (fat, protein, and lactose) was determined once weekly from successive morning and evening milk samples by automated infrared absorption analysis (MilkoScan 605; Foss Electric, Hillerød, Denmark). Milk samples were obtained from the electronic meters as each cow was milked. Weighted fat, protein, and lactose concentrations were calculated based on the morning and evening milk yields giving one value for each component per cow weekly. Solids-corrected milk yield was calculated using the equation of Tyrrell and Reid (1965). Milk N output was calculated as the milk protein yield $\div 6.38$. Milking took place at 0700 and $1530 \mathrm{~h}$ daily for the duration of the experiment. Milk samples were taken during consecutive morning and evening milking periods for determination of MUN in association with 2 urine sampling periods during wk 6 and 10 of the study. Individual cow BW was measured once weekly after morning milking using electronic scales (Tru-Test Ltd., Auckland, New Zealand). Individual cow BCS (Lowman et al., 1976) was determined 
once weekly on a scale of 1 (thinnest) to 5 (fattest) in conjunction with the BW measurement.

Urine samples were collected, following vulval stimulation, for the analysis of allantoin and creatinine concentrations in 2 periods for $5 \mathrm{~d}$ before the evening milking. It was decided that all cows should be on trial for at least $3 \mathrm{wk}$ before the first sampling period to allow them to acclimate to treatments, and at least $7 \mathrm{wk}$ before the second sampling period to allow a sufficient interval between periods. Due to the different experiment start dates imposed, sampling took place on wk 6 and 10 of the experiment to allow all cows to be sampled together. Before sampling, $1 \mathrm{~mL}$ of $9 \mathrm{M} \mathrm{H}_{2} \mathrm{SO}_{4}(25 \%$ solution) was placed in all the sample bottles to acidify the urine to prevent ammonia volatilization. A $100-\mathrm{mL}$ sample of urine was added to each sample bottle to ensure an even degree of acidification between samples. All samples were then frozen, and subsequently thawed and composited for the 5-d period to give a representative sample for each cow during each period ( $\mathrm{n}=56 \mathrm{per}$ collection period). Samples were analyzed for allantoin and creatinine concentrations. Gross efficiency of N utilization was calculated as the proportion of ingested $\mathrm{N}$ excreted in milk.

Blood samples were collected from the coccygeal vessels of all cows (after morning milking) once during each urine-sampling period (total of 2 samples per cow). Samples were collected into Vacutainers (Becton and Dickinson UK Ltd., Cowley, Oxford, UK) coated with lithium heparin as an anticoagulant. The samples were immediately placed on ice packs and processed within $1 \mathrm{~h}$ of sampling. The samples were centrifuged at 3,500 $\times g$ at $0^{\circ} \mathrm{C}$ for $10 \mathrm{~min}$; the plasma was decanted and frozen at $-18^{\circ} \mathrm{C}$ before analysis for glucose, NEFA, BHBA, urea, and total protein.

\section{Rumen Degradability}

Ruminal degradability of each of the 4 forages and 3 concentrates was measured in situ using three 5-yr-old Holstein-Friesian steers. The degradability measurements were carried out as previously described by Mulligan et al. (2002), with the exception that only 6 incubation times were used: $2,4,8,12,24$, and $48 \mathrm{~h}$. After removal from the rumen, the nylon bags were rinsed in cold water. They were then subjected to mechanical pummeling (stomaching) for $5 \mathrm{~min}$, which consisted of repetitive physical beating of the sample bags by 2 metal plates in a bicarbonate buffer solution using a Lab Blender 400 (Seward Medical, London, UK). After stomaching, bags were washed in a twin-tub washing machine, placed on a tray, and dried in an oven at $80^{\circ} \mathrm{C}$ for $48 \mathrm{~h}$. Washing and stomaching of the nylon bags was carried out as described by Mulligan et al. (2002).
Testing for microbial contamination was not conducted because Merry and McAllan (1983) previously found that the stomaching procedure was successful in removing bacterial contamination. The rapidly soluble fraction of DM and N (termed "a"), the insoluble but potentially degradable fraction (termed "b"), and the rate of degradation of "b" (termed "c"), were determined using the model of Michalet-Doreau et al. (1987) and these coefficients were used to determine effective degradability according to Ørskov and McDonald (1979) using an outflow rate of $0.06 \mathrm{~h}^{-1}$. The PDIN and PDIE values were calculated using data obtained from degradability and chemical analysis according to Vérité and Peyraud (1989).

\section{Laboratory Procedures and Analysis}

The forage and concentrate samples were stored at $-18^{\circ} \mathrm{C}$ and analyzed at the end of the experiment. Forage samples were then dried at $40^{\circ} \mathrm{C}$ for $48 \mathrm{~h}$, whereas concentrate samples were dried at $95^{\circ} \mathrm{C}$ for $16 \mathrm{~h}$. Samples were analyzed for CP, NDF, ash, starch, DM digestibility (DMD), OM digestibility (OMD), and digestible OM concentration in the DM (DOMD) according to the methods referenced in McNamara et al. (2003). The respective DOMD values were used to predict ME concentration using equation number 58 in Energy Allowances and Feeding Systems for Ruminants (Ministry of Agriculture, Fisheries and Food, 1987). Starch concentration was determined colorimetrically (Megazyme kit; Megazyme International Ireland Ltd., Bray, Co. Wicklow, Ireland; McCleary et al., 1997). Further subsamples of forage and concentrate were dried at $60^{\circ} \mathrm{C}$ and were used to determine ether extract concentration (AOAC, 1990). Undried samples of preserved forage were used for the determination of ammonia-N, lactate, acetate, propionate, butyrate, valerate, ethanol, and propanol; analyses were carried out by wet chemistry according to the methods described by Porter et al. (1995). The $\mathrm{pH}$ was measured in juice pressed from the forages using a glass electrode and a $\mathrm{pH}$ meter (pHM2 standard pH meter-radiometer; Radiometer, Copenhagen, Denmark). Urea concentration in milk was determined using a colorimetric method ( $\mathrm{R}$ Biopharm urea/ ammonia kit). All blood analyses were carried out using appropriate kits on an ABX Mira autoanalyzer (ABX Mira, Cedex 4, France). The metabolites analyzed were glucose, NEFA, BHBA, urea, and total protein. The N concentration of the urine samples as well as the $\mathrm{N}$ content of the residues in the degradability bags was measured on a Leco FP528 N analyzer (Leco, Hazel Grove, Stockport, UK). Urine samples were analyzed for allantoin by the method of Borcher (1977) and for creatinine using a Randox colorimetric method (cat. no. 
510; Randox Laboratories Ltd., Crumlin, Co. Antrim, UK).

The following procedure was developed to obtain an estimate of the degree of grain processing achieved during harvesting. Two 100 - to 150 -g subsamples were taken from a larger representative sample obtained from the fermented WCW and urea-treated processed WCW silos midway through the experiment. The subsamples were dried overnight at $95^{\circ} \mathrm{C}$. They were then placed on a large white tray and separated in good light into 3 components: straw, whole unprocessed grain, and milled or shattered/damaged grain. After completion of the separation, the 3 components were placed in an oven again, dried for $4 \mathrm{~h}$ at $103^{\circ} \mathrm{C}$, and then reweighed. Each component was then expressed as a percentage of the total dry weight.

\section{Statistical Analysis}

A mixed model using PROC MIXED (SAS Institute, 2005) was used to analyze the data for milk yield, milk constituent yield, milk composition, BW and BCS, DM, PDIN and PDIE intake, RDP balance, ME intake, ME output, ME balance, $\mathrm{N}$ output in milk and efficiency of ingested $\mathrm{N}$, blood metabolites, and urine constituents. The class variables included in the model for milk yield, milk constituent yield, milk composition, BW and BCS, DM, PDIN and PDIE intake, RDP balance, ME intake, ME output, $\mathrm{ME}$ balance, $\mathrm{N}$ output in milk, and efficiency of ingested $\mathrm{N}$ were experimental week, treatment, and block; the class variables included in the model for blood metabolites and urine constituents were time, treatment, and block; cow was included as a repeated effect. Least squares means were obtained and differences between means were tested for significance using the $t$-test following the Tukey adjustment for multiple comparisons. The BW change and BCS change were calculated by subtracting the respective values in the first week of the experiment from those in the final week and were subsequently analyzed using PROC GLM (SAS Institute, 2005). Class variables included in the model were treatment and block. Least squares means were again obtained and compared using the $t$-test.

\section{RESULTS}

\section{Chemical Composition of Forage and Concentrates}

Table 2 shows the mean chemical composition of the forages for the experimental period. These data were not subjected to statistical analysis. There was a large variation in DM between the different forages as anticipated. The CP concentration in the urea-treated processed WCW was greater than in the fermented WCW and corn silage, which had similar concentrations. The grass silage had a CP concentration of $179 \mathrm{~g}$ of $\mathrm{CP} / \mathrm{kg}$ of DM and an in vitro DMD of $761 \mathrm{~g} / \mathrm{kg}$, indicating good quality. The ME contents of the treatments as predicted from DOMD were 11.3, 11.0, 12.1, and $12.1 \mathrm{MJ} / \mathrm{kg}$ of DM for grass silage, fermented WCW, urea-treated processed WCW, and corn silage, respectively. In relation to the degree of grain processing, grain accounted for $330 \mathrm{~g} / \mathrm{kg}$ of DM in F-WCW and $640 \mathrm{~g} / \mathrm{kg}$ of DM in UPWCW. Thirty-eight percent of the grain in the fermented WCW was cracked or processed compared with $59 \%$ cracked or processed in the urea-treated processed WCW. The 230 and $250 \mathrm{~g} / \mathrm{kg} \mathrm{CP}$ concentrates had slightly lower CP concentrations than desired at 221 and $240 \mathrm{~g} / \mathrm{kg}$ as-fed, respectively.

\section{Forage and Concentrate Intake}

The 3 mixed forage treatments (F-WCW, UP-WCW, and CS) resulted in greater $(P<0.001)$ forage DMI than GS (Table 3). Treatment UP-WCW resulted in the greatest forage DMI and was greater $(P<0.001)$ than CS, which was in turn greater $(P<0.001)$ than F-WCW. Concentrate DMI was similar $(P=0.19)$ for GS, FWCW, and CS, but lower $(P<0.05)$ for UP-WCW than for F-WCW and CS. Total DMI followed a pattern across treatments that was similar to forage DMI.

\section{Milk Production and Composition}

Treatment GS had lower $(P<0.001)$ milk yield and solids-corrected milk yield than UP-WCW and CS. Milk and solids-corrected milk yields were greater $(P<0.001)$ on CS than on all other treatments (Table 3). Milk fat and protein yields were greater $(P<0.001)$ on the 3 mixed forage treatments than on GS. Milk protein yield was also greater $(P<0.001)$ on CS than on F-WCW. Milk lactose yield was greater $(P<0.001)$ on UP-WCW and CS than on GS but not F-WCW. There was no significant difference in milk fat or lactose concentrations between treatments. Milk protein concentration was similar on F-WCW, UP-WCW, and CS, but was greater $(P<0.001)$ on all 3 than on GS. There was no significant difference in average BW, BCS, or BCS change between treatments. Cows on GS lost more $(P$ $<0.05)$ BW than cows on UP-WCW and CS. The ME intake was greater $(P<0.001)$ on UP-WCW and CS than on F-WCW, which was, in turn, greater $(P<0.001)$ than on GS. Output of ME was lower $(P<0.001)$ on GS than on all other treatments. The ME balance was greater $(P<0.001)$ on UP-WCW than on GS, F-WCW, or UP-WCW, which were not significantly different from each other. 
Table 2. Chemical composition of forages offered

\begin{tabular}{|c|c|c|c|c|}
\hline \multirow[b]{2}{*}{ Item $^{1}$} & \multicolumn{4}{|c|}{ Forage } \\
\hline & $\begin{array}{l}\text { Grass } \\
\text { silage }\end{array}$ & $\begin{array}{l}\text { Fermented } \\
\text { WCW }^{2}\end{array}$ & $\begin{array}{l}\text { Urea- } \\
\text { treated } \\
\text { processed } \\
\text { WCW }^{2}\end{array}$ & $\begin{array}{l}\text { Corn } \\
\text { silage }\end{array}$ \\
\hline $\mathrm{DM}, \mathrm{g} / \mathrm{kg}$ & 204 & 389 & 795 & 346 \\
\hline \multicolumn{5}{|l|}{ DM composition, g/kg } \\
\hline $\mathrm{CP}$ & 179 & 90 & 141 & 93 \\
\hline NDF & 565 & 391 & 360 & 390 \\
\hline Ash & 74 & 38 & 30 & 42 \\
\hline Starch & 0 & 316 & 382 & 301 \\
\hline Ether extract & 45 & 25 & 20 & 30 \\
\hline DMD & 762 & 711 & 768 & 783 \\
\hline OMD & 761 & 717 & 781 & 788 \\
\hline DOMD & 705 & 690 & 758 & 756 \\
\hline $\mathrm{ME},{ }^{3} \mathrm{MJ} / \mathrm{kg}$ of $\mathrm{DM}$ & 10.6 & 10.3 & 11.4 & 12.1 \\
\hline PDIN & 104 & 55 & 85 & 57 \\
\hline PDIE & 75 & 75 & 80 & 85 \\
\hline \multicolumn{5}{|c|}{ Fermentation characteristics, $\mathrm{g} / \mathrm{kg}$ of $\mathrm{DM}$} \\
\hline Lactic acid & 39 & $\mathrm{ND}^{4}$ & ND & 43 \\
\hline Acetic acid & 33 & 1 & 3 & 21 \\
\hline Propionic acid & 3 & ND & ND & 1 \\
\hline Butyric acid & 2 & ND & ND & ND \\
\hline Ethanol & 7 & ND & ND & 1 \\
\hline Propanol & 7 & ND & ND & ND \\
\hline $\mathrm{pH}$ & 3.9 & 4.3 & 7.8 & 3.9 \\
\hline Ammonia-N, $\mathrm{g} / \mathrm{kg}$ of total $\mathrm{N}$ & 89 & 20 & 110 & 67 \\
\hline
\end{tabular}

${ }^{1} \mathrm{DMD}=\mathrm{DM}$ Digestibility; OMD = OM digestibility; DOMD = digestible OM concentration in the DM; PDIN = True protein digested in the small intestine when fermentable $\mathrm{N}$ is limiting; PDIE = True protein digested in the small intestine when fermentable energy is limiting.

${ }^{2} \mathrm{WCW}=$ Whole-crop wheat.

${ }^{3}$ Estimated based on DOMD (Ministry of Agriculture, Fisheries and Food, 1987).

${ }^{4} \mathrm{ND}=$ Not detected.

Table 3. The effect of treatment on DMI, milk yield, milk composition, BW, BCS, and ME balance

\begin{tabular}{lccccc}
\hline & \multicolumn{4}{c}{ Forage $^{1}$} \\
\cline { 2 - 4 } & GS & F-WCW & UP-WCW & CS & SEM \\
\hline Concentrate DMI, kg/d & $5.9^{\mathrm{ab}}$ & $6.2^{\mathrm{a}}$ & $5.8^{\mathrm{b}}$ & $6.2^{\mathrm{a}}$ & 0.11 \\
Forage DMI, kg/d & $7.6^{\mathrm{d}}$ & $10.9^{\mathrm{c}}$ & $14.4^{\mathrm{a}}$ & $12.1^{\mathrm{b}}$ & 0.29 \\
Total DMI, kg/d & $13.5^{\mathrm{d}}$ & $17.1^{\mathrm{c}}$ & $20.0^{\mathrm{a}}$ & $18.3^{\mathrm{b}}$ & 0.32 \\
ME intake, MJ/d & $153.9^{\mathrm{c}}$ & $192.8^{\mathrm{b}}$ & $233.1^{\mathrm{a}}$ & $219.4^{\mathrm{a}}$ & 3.77 \\
Milk yield, kg/d & $26.5^{\mathrm{c}}$ & $29.2^{\mathrm{bc}}$ & $30.2^{\mathrm{b}}$ & $33.2^{\mathrm{a}}$ & 0.85 \\
Milk fat, kg/d & $0.91^{\mathrm{b}}$ & $1.12^{\mathrm{a}}$ & $1.10^{\mathrm{a}}$ & $1.20^{\mathrm{a}}$ & 0.045 \\
Milk protein, kg/d & $0.77^{\mathrm{c}}$ & $0.90^{\mathrm{b}}$ & $0.94^{\mathrm{ab}}$ & $1.02^{\mathrm{a}}$ & 0.027 \\
Milk lactose, kg/d & $1.22^{\mathrm{c}}$ & $1.34^{\mathrm{bc}}$ & $1.43^{\mathrm{b}}$ & $1.57^{\mathrm{a}}$ & 0.043 \\
Milk fat and protein, kg/d & $1.62^{\mathrm{c}}$ & $1.98^{\mathrm{b}}$ & $1.99^{\mathrm{b}}$ & $2.22^{\mathrm{a}}$ & 0.081 \\
Solids-corrected milk, kg/d & $25.2^{\mathrm{c}}$ & $27.7^{\mathrm{bc}}$ & $28.6^{\mathrm{b}}$ & $31.6^{\mathrm{a}}$ & 0.82 \\
Milk fat, g/kg & $33.5^{\mathrm{b}}$ & 37.9 & 35.4 & 35.5 & 1.17 \\
Milk protein, g/kg & $28.5^{\mathrm{b}}$ & $30.5^{\mathrm{a}}$ & $31.3^{\mathrm{a}}$ & $30.7^{\mathrm{a}}$ & 0.47 \\
Milk lactose, g/kg & $46.7^{\mathrm{a}}$ & 45.8 & 48.1 & 47.4 & 0.75 \\
BW, kg & 564 & 594 & 595 & 13.6 \\
BW change, kg/d & $-0.27^{\mathrm{b}}$ & $-0.06^{\mathrm{ab}}$ & $-0.01^{\mathrm{a}}$ & $0.05^{\mathrm{a}}$ & 0.08 \\
BCS & 2.84 & 2.93 & 3.07 & 2.96 & 0.09 \\
BCS change & -0.18 & -0.18 & -0.28 & -0.11 & 0.09 \\
ME output, MJ/d & $168.5^{\mathrm{b}}$ & $202.3^{\mathrm{a}}$ & $201.9^{\mathrm{a}}$ & $221.0^{\mathrm{a}}$ & 4.97 \\
ME balance, ${ }^{2} \mathrm{MJ} / \mathrm{d}$ & $-14.6^{\mathrm{b}}$ & $-9.6^{\mathrm{b}}$ & $31.2^{\mathrm{a}}$ & $-1.53^{\mathrm{b}}$ & 4.05 \\
\hline
\end{tabular}

${ }^{\mathrm{a}-\mathrm{d}}$ Means within rows having different superscripts differ significantly $(P<0.05)$.

${ }^{1}$ Forages: GS = grass silage; F-WCW = fermented whole-crop wheat; UP-WCW = urea-treated processed whole-crop wheat; $\mathrm{CS}=$ corn silage.

${ }^{2} \mathrm{ME}$ balance $=\mathrm{ME}$ intake $-\mathrm{ME}$ output. 
Table 4. Effect of treatment on blood metabolites

\begin{tabular}{lccccc}
\hline & \multicolumn{3}{c}{ Forage $^{1}$} & \\
\cline { 2 - 5 } & GS & F-WCW & UP-WCW & CS & SEM \\
\hline Glucose, mmol/L & 4.03 & 3.93 & 3.98 & 4.13 & 0.108 \\
NEFA, mmol/L & 0.08 & 0.15 & 0.18 & 0.13 & 0.025 \\
BHBA, mmol/L & 0.72 & 0.62 & 0.68 & 0.64 & 0.049 \\
Total protein, g/L & 97.7 & 98.6 & 93.7 & 98.7 & 2.47 \\
Urea, mmol/L & 5.86 & 6.09 & 6.29 & 6.62 & 0.346 \\
\hline
\end{tabular}

\footnotetext{
${ }^{1}$ Forages: GS = grass silage; F-WCW = fermented whole-crop wheat; UP-WCW = urea-treated processed
} whole-crop wheat; $\mathrm{CS}=$ corn silage.

\section{Blood Metabolites}

The mean of blood metabolites in samples taken at 2 times showed no significant difference between treatments (Table 4).

\section{PDIN, PDIE, and N Balance}

Treatment GS had a lower $(P<0.001) \mathrm{N}$ intake than the other treatments, and $\mathrm{N}$ intake was greater $(P<$ 0.001) on UP-WCW than on F-WCW or CS (Table 5). The greatest PDIN supply was obtained on UP-WCW, which was greater $(P<0.001)$ than on F-WCW or CS. Both F-WCW and CS had a greater $(P<0.001)$ PDIN supply than GS. Similarly, PDIE supply was lower $(P$ $<0.001)$ on GS than on the other treatments. The PDIE supply was greater $(P<0.001)$ on UP-WCW and CS than on F-WCW. The PDI (true protein digested in the small intestine) requirements based on maintenance and milk production were 1,537, 1,747, 1,805, and 1,928 g/d for GS, F-WCW, UP-WCW, and CS, respectively. Based on PDI supply and requirements, GS was defi- cient in PDI by $186 \mathrm{~g} / \mathrm{d}$, whereas F-WCW, UP-WCW, and CS supplied an excess of PDI of 124, 259, and 111 $\mathrm{g} / \mathrm{d}$, respectively.

Output of $\mathrm{N}$ in milk was lower $(P<0.001)$ on GS than on the other treatments, and milk $\mathrm{N}$ output was greater $(P<0.001)$ on $\mathrm{CS}$ than on F-WCW with UP-WCW intermediate $(P=0.81)$ between the 2 . Treatments GS and UP-WCW had a lower $(P<0.001)$ proportion of consumed $\mathrm{N}$ excreted in milk than F-WCW and CS; the proportion was greater $(P<0.001)$ on CS than on F-WCW. There was no significant difference in MUN concentration between treatments. There was no significant difference in urinary allantoin concentration, creatinine concentration, or allantoin $\mathrm{N}$ :creatinine $\mathrm{N}$ ratio between treatments.

\section{DISCUSSION}

\section{Forage Analysis}

When considering the results of the current experiment, it is important to bear in mind that the quality

Table 5. Nitrogen utilization

\begin{tabular}{|c|c|c|c|c|c|}
\hline & \multicolumn{4}{|c|}{ Forage $^{1}$} & \multirow[b]{2}{*}{ SEM } \\
\hline & GS & F-WCW & UP-WCW & CS & \\
\hline $\mathrm{N}$ intake, $\mathrm{g} / \mathrm{d}$ & $415^{\mathrm{c}}$ & $442^{\mathrm{b}}$ & $566^{\mathrm{a}}$ & $456^{\mathrm{b}}$ & 7.7 \\
\hline PDIN intake, g/d & $1,635^{\mathrm{c}}$ & $1,994^{\mathrm{b}}$ & $2,363^{\mathrm{a}}$ & $2,095^{\mathrm{b}}$ & 32.5 \\
\hline PDIE intake, g/d & $1,351^{\mathrm{c}}$ & $1,871^{\mathrm{b}}$ & $2,064^{\mathrm{a}}$ & $2,039^{\mathrm{a}}$ & 30.4 \\
\hline RDP balance, ${ }^{2} \mathrm{~g} / \mathrm{d}$ & $284^{\mathrm{c}}$ & $124^{\mathrm{b}}$ & $302^{\mathrm{c}}$ & $56^{\mathrm{a}}$ & 6.8 \\
\hline \multicolumn{6}{|l|}{ Milk N } \\
\hline Output, g/d . & $117^{\mathrm{c}}$ & $140^{\mathrm{b}}$ & $146^{\mathrm{ab}}$ & $161^{\mathrm{a}}$ & 4.9 \\
\hline Proportion of $\mathrm{N}$ intake & $0.28^{\mathrm{c}}$ & $0.32^{\mathrm{b}}$ & $0.26^{\mathrm{c}}$ & $0.36^{\mathrm{a}}$ & 0.008 \\
\hline MUN, mmol/L & 2.8 & 3.0 & 3.0 & 2.7 & 0.11 \\
\hline \multicolumn{6}{|l|}{ Urine $\mathrm{N}$} \\
\hline Allantoin, mmol/L & 11.3 & 14.3 & 13.9 & 11.6 & 0.89 \\
\hline Creatinine, $\mathrm{mmol} / \mathrm{L}$ & 8.7 & 9.9 & 10.5 & 8.3 & 0.64 \\
\hline Allantoin N:Creatinine $\mathrm{N}$ & 1.35 & 1.47 & 1.34 & 1.41 & 0.061 \\
\hline \multicolumn{6}{|c|}{${ }^{\mathrm{a}-\mathrm{c}}$ Means within rows having different superscripts differ significantly $(P<0.05)$} \\
\hline \multicolumn{6}{|c|}{$\begin{array}{l}{ }^{1} \text { Forages: GS = grass silage; F-WCW = fermented whole-crop wheat; UP-WCW = urea-treated processed } \\
\text { whole-crop wheat; CS = corn silage. }\end{array}$} \\
\hline \multicolumn{6}{|c|}{$\begin{array}{l}{ }^{2} \mathrm{RDP} \text { balance }=\text { PDIN intake }-\mathrm{PDIE} \text { intake. PDIN }=\text { true protein digested in the small intestine when } \\
\text { fermentable } \mathrm{N} \text { is limiting; PDIE = true protein digested in the small intestine when fermentable energy is } \\
\text { limiting. }\end{array}$} \\
\hline
\end{tabular}


of the grass silage used as the basal forage was excellent. It had a DMD value of $762 \mathrm{~g} / \mathrm{kg}$ of DM with an ammonia-N concentration of $89 \mathrm{~g} / \mathrm{kg}$ of total $\mathrm{N}$ and a $\mathrm{pH}$ value of 3.9. The maturing of the wheat crop from $414 \mathrm{~g} / \mathrm{kg}$ of DM for fermented WCW to $750 \mathrm{~g} / \mathrm{kg}$ of DM for urea-treated processed WCW led to changes in nutritive value. The normal trend that occurs with an increase in DM content is an increase in lignification of stem and leaves, a decline in water-soluble carbohydrates and an increase in starch content (Leaver and Hill, 1995). As grain fill progresses, the increase in starch compensates to some extent for the increase in $\mathrm{NDF}$ and ADF content, and the fiber content of the total crop is not substantially changed (Leaver and Hill, 1995). In this experiment, the higher cutting height used for the urea-treated processed WCW also contributed to lowering the fiber content of the total crop, mainly due to the lower overall straw content. The in vitro DMD of the fermented WCW $(711 \mathrm{~g} / \mathrm{kg}$ of DM) and urea-treated processed WCW (768 g/kg of DM) were both high. The harvested corn silage was a mature crop with DM $(346 \mathrm{~g} / \mathrm{kg})$ and $\operatorname{starch}(301 \mathrm{~g} / \mathrm{kg})$ concentrations that would be similar to those in a good-quality commercial crop in Ireland.

\section{Forage and Concentrate DMI}

The intake results clearly indicated that substituting fermented WCW, urea-treated processed WCW, or corn silage for grass silage increased DMI. Abdalla et al. (1999), Leaver and Hill (1995), Phipps et al. (1995), and Sutton et al. (1998) obtained similar results using fermented WCW and urea-treated unprocessed WCW. For corn and grass silage mixtures, a significant increase in DMI over grass silage alone was reported by Phipps et al. (1995) and O'Mara et al. (1998). In the current study, the highest forage intake was recorded for cows offered UP-WCW and this is likely to be due to the high DM content of this forage mixture. The DM content of urea-treated processed WCW was much greater than that of fermented WCW, which is the most likely reason for the significant difference in DMI between the 2 forages.

In contrast to Phipps et al. (1995), treatment CS did not produce the largest increase in forage intake over GS. In fact, in the current study, DMI on CS was significantly lower than on UP-WCW but significantly higher than on F-WCW. This is in agreement with Murphy et al. (2004) and Sinclair et al. (2005), who reported a higher DMI from urea-treated processed WCW-based diets than from corn silage-based diets. The DMI obtained for treatment GS in the current study, was lower than that achieved in other studies (Phipps et al., 1995; Hameleers, 1998; Phipps et al., 2000). Previous studies have indicated enormous variation in the intake potential of grass silage by cattle (Steen et al., 1998). The relatively low DM content as well as the less than ideal fermentation quality, as indicated by the low lactic acid concentration, may have been responsible for this.

\section{Milk Production, Milk Composition, and BW}

The increased milk and solids-corrected milk production achieved with the inclusion of fermented WCW and urea-treated processed WCW in the diet differs from results of previous studies (Leaver and Hill, 1995; Phipps et al., 1995; Sutton et al., 1998, 2001; Hameleers, 1998; Abdalla et al., 1999). In these studies, there was no increase in milk yield when fermented WCW and urea-treated WCW were included. It should be noted that the urea-treated WCW offered in those experiments was unprocessed. This suggests that the processing may have some beneficial effect on milk production although further experimentation would be required to confirm this. In a study in which urea-treated processed WCW was used, Murphy et al. (2004) reported a milk yield increase when compared with grass silage. In terms of the corn silage, the significant increase in milk yield is supported by previous results (Phipps et al., 1995, 2000; O'Mara et al., 1998). Compared with GS, the milk yield increases recorded on FWCW and particularly on UP-WCW are low compared with those observed with CS. This is particularly interesting considering the relatively high DMI for treatment UP-WCW relative to treatment CS. This poor response in milk yield relative to DMI is in agreement with results of other experiments (Leaver and Hill, 1995; Phipps et al., 1995; Sutton et al., 1998; Abdalla et al., 1999). It has been suggested that the increase in forage intake is accompanied by a considerable reduction in ruminal DM digestibility and that the inclusion of whole-crop cereals in the diet may have increased the rate of passage of undigested grain from the rumen (Abdalla et al., 1999). Given that only 59\% of the ureatreated processed WCW grain was cracked or processed in the current experiment, the digestibility of the starch may not have been greatly improved. Leaver and Hill (1995) suggested that poor utilization of whole-crop cereals, and in particular urea-treated whole crop, may be due to the high intake of ammonia from the hydrolyzed urea, which has then to be metabolized and excreted (requiring further energy to do so).

The increased fat and protein yield obtained here due to inclusion of other forages with grass silage has also been reported in other studies (O'Mara et al., 1998; Phipps et al., 2000). In agreement with O'Mara et al. (1998), milk lactose yield was also significantly improved by including corn silage in the diet. In contrast 
to other studies (Leaver and Hill, 1995; Hameleers, 1998), a significant improvement in milk fat and protein yield was achieved by offering fermented WCW with grass silage in the current study. Similarly, Sinclair et al. (2005) reported no advantage of urea-treated processed WCW over corn silage for milk fat, protein, or lactose yield. In the present study, a significant improvement in milk protein concentration was achieved by feeding fermented WCW, urea-treated processed WCW, or corn silage with grass silage. The absence of an effect of treatment on milk fat and lactose concentrations agrees with the findings of Leaver and Hill (1995), Phipps et al. (1995), Sutton et al. (1998), and Hameleers (1998).

The BW gain per day was greater for UP-WCW and CS than for GS, which was also observed by Phipps et al. (1995) for corn silage inclusion. This is probably a reflection of greater energy intakes as a result of the greater DMI. The ME balances of GS, F-WCW, and CS were not significantly different and broadly reflected the differences in milk production and BW changes between the treatments. The ME balance of UP-WCW was highly positive, which may indicate that its ME was overestimated from DOMD. Samples of forage analyzed for DOMD were ground samples, which meant that the entire grain fraction was processed; this would not be the same as the forage offered, which was estimated to have only $59 \%$ of the grain processed.

\section{Blood Metabolites}

The average blood metabolite concentrations at $\mathrm{d} 64$ \pm 17.4 and $d 92 \pm 17.4$ postpartum were similar between treatments and were generally within normal ranges (Whitaker et al., 1983; Mee and Nolan, 1994) suggesting that animals were not nutritionally stressed by the diets offered at these times. The absence of an effect on plasma urea concentrations is probably the result of formulating the concentrates to balance dietary $\mathrm{CP}$ concentrations.

\section{Nitrogen Utilization}

A large proportion of $\mathrm{N}$ intake by dairy cattle is not recovered in milk (Castillo et al., 2000), with up to $70 \%$ being excreted in the urine and feces. In the current experiment, the inefficiency of $\mathrm{N}$ utilization ranged from 0.64 for CS to 0.74 for UP-WCW. Similar values were reported by Castillo et al. (2001) and Mulligan et al. (2004) for lactating cow diets. The lower efficiency of N utilization on UP-WCW and GS is likely the result of the greater RDP balance (PDIN intake - PDIE intake) on these treatments. In addition, the high efficiency of $\mathrm{N}$ utilization achieved on CS suggests that balancing the level of PDIN and PDIE in the diet is beneficial in improving the efficiency of $\mathrm{N}$ utilization as indicated by the results of Colin-Schoellen et al. (2000). Milk urea concentration has been suggested as an indicator of $\mathrm{N}$ excretion from dairy cows (Gonda and Lindberg, 1994). Vérité et al. (1996) suggested a MUN threshold concentration of $1.4 \mathrm{mmol} / \mathrm{L}$ for conserved diets, below which there is a risk that protein deficiency could limit animal performance, whereas at concentrations greater than $2.1 \mathrm{mmol} / \mathrm{L}$, there is a risk of excessive $\mathrm{N}$ wastage. The higher values obtained here (average of $2.9 \mathrm{mmol} / \mathrm{L}$ ), despite the PDI supply calculation indicating a deficiency on GS, indicated a surplus of $\mathrm{N}$ in all treatments.

\section{CONCLUSIONS}

The results of this study indicate that replacing 670 $\mathrm{g} / \mathrm{kg} \mathrm{DM}$ of grass silage with fermented WCW, ureatreated processed WCW, or corn silage can have a positive effect on DMI and milk protein concentration. An improvement in daily milk yield may also be achieved by offering urea-treated processed WCW and corn silage. These forages also had a positive effect in reducing BW loss in early lactation. The greatest efficiency of $\mathrm{N}$ utilization among these diets was achieved by offering a mixture of corn and grass silages; in contrast, the lowest efficiency of $\mathrm{N}$ utilization was obtained when grass silage was offered as the sole forage or with ureatreated processed WCW. In terms of increasing overall milk production and improving $\mathrm{N}$ utilization, these results suggest that corn silage is likely to be superior to fermented or urea-treated processed WCW in mixtures with grass silage.

\section{ACKNOWLEDGMENTS}

The authors would like to thank J. P. Murphy, J. Kenneally, and the Moorepark farm staff for management and care of the animals. The technical assistance of F. Flynn, J. Nash, M. Feeney, N. Galvin, C. Fleming, and C. McCarney is also appreciated.

\section{REFERENCES}

Abdalla, A. L., J. D. Sutton, R. H. Phipps, and D. J. Humphries. 1999. Digestion in the rumen of lactating dairy cows given mixtures of urea-treated whole-crop wheat and grass silage. Anim. Sci. 69:203-212.

AOAC. 1990. Official Methods of Analysis. 15th ed. Association of Official Analytical Chemists, Arlington, VA.

Borcher, R. 1977. Allantoin determination. Anal. Biochem. 79:612613.

Castillo, A. R., E. Kebreab, D. E. Beever, J. H. Barbi, J. D. Sutton, H. C. Kirby, and J. France. 2001. The effect of protein supplementation on nitrogen utilization in lactating dairy cows fed grass silage diets. J. Anim. Sci. 79:247-253. 
Castillo, A. R., E. Kebreab, D. E. Beever, and J. France. 2000. A review of efficiency of nitrogen utilisation in lactating dairy cows and its relationship with environmental pollution. J. Anim. Feed Sci. 9:1-32.

Colin-Schoellen, O., S. Jurjanz, and F. Laurent. 2000. Metabolizable protein supply (PDIE) and restricted level of ruminally degradable nitrogen (PDIN) in total mixed rations: Effect on milk production and composition and on the nitrogen utilization by dairy cows. Livest. Prod. Sci. 67:41-53.

Gonda, H. L., and J. E. Lindberg. 1994. Evaluation of dietary nitrogen utilization in dairy cows based on urea concentrations in blood, urine and milk, and on urinary concentration of purine derivatives. Acta Agric. Scand. A, Anim. Sci. 44:236-245.

Hameleers, A. 1998. The effects of the inclusion of either corn silage, fermented whole crop wheat or urea-treated whole crop wheat in a diet based on a high-quality grass silage on the performance of dairy cows. Grass Forage Sci. 53:157-163.

Leaver, J. D., and J. Hill. 1995. The performance of dairy cows offered ensiled while-crop wheat, urea-treated whole crop wheat or sodium hydroxide-treated wheat grain and wheat straw in a mixture with grass silage. Anim. Sci. 61:481-489.

Lowman, B. G., N. Scott, and S. Somerville. 1976. Condition scoring of cattle. Rev. ed. Bull. No. 6, East of Scotland College of Agric., The Edinburgh School of Agriculture, Edinburgh, UK.

Mee, J. F., and M. Nolan. 1994. Summer mini-metabolic profile of 50 spring-calving dairy herds. Pages $40-41$ in Moorepark Research and Development Division Research Report, Teagasc, Moorepark, Ireland.

Merry, T. J., and A. B. McAllan. 1983. A comparison of the chemical composition of mixed bacteria harvested from the liquid and solid fractions of rumen digesta. Br. J. Nutr. 50:701-709.

Michalet-Doreau, B., R. Vérité, and P. Chapoutot. 1987. Methodologie de mesure de la degradabilite in sacco de l'azote des aliments dans le rumen. Bull. Tech. C.R.Z.V. Theix 69:5-7.

Ministry of Agriculture, Fisheries and Food. 1987. Energy Allowances and Feeding Systems for Ruminants. Reference book 433, page 71. Her Majesty's Stationery Office, London, UK.

Mulligan, F. J., P. Dillon, J. J. Callan, M. Rath, and F. P. O'Mara. 2004. Supplementary concentrate type affects nitrogen excretion of grazing dairy cows. J. Dairy Sci. 87:3451-3460.

Mulligan, F. J., J. Quirke, M. Rath, P. J. Caffrey, and F. P. O’Mara. 2002. Intake, digestibility, milk production, and kinetics of digestion and passage for diets based on corn or grass silage fed to late lactation dairy cows. Livest. Prod. Sci. 74:113-124.

Murphy, J. J., S. Kavanagh, and J. J. Fitzgerald. 2004. Comparative evaluation of grass silage, fermented whole crop wheat silage, urea-treated processed whole crop wheat silage and corn silage in the diet of early lactation cows. Page 95 in Book of Abstracts No. 10, Eur. Assoc. Anim. Prod., Wageningen Academic Publishers, Wageningen, the Netherlands.

McCleary, B. V., C. C. Gibson, and C. C. Mugford. 1997. Measurements of total starch in cereal products by amyloglucosidase- $\alpha$ amylase method. Collaborative study. J. AOAC Int. 80:571-579.

McNamara, S., F. P. O'Mara, M. Rath, and J. J. Murphy. 2003. Effects of different transition diets on energy balance, blood metabolites, and reproductive performance in dairy cows. J. Dairy Sci. 86:2397-2408.

National Research Council. 2001. Nutrient Requirements of Dairy Cattle. 7th rev. ed. National Academic Press, Washington, DC.

O'Mara, F. P., J. J. Fitzgerald, J. J. Murphy, and M. Rath. 1998. The effect on milk production of replacing grass silage with corn silage in the diet of dairy cows. Livest. Prod. Sci. 55:79-87.

Ørskov, E. R., and I. McDonald. 1979. The estimation of protein degradability in the rumen from incubation measurements weighted according to rate of passage. J. Agric. Sci. (Camb.) 92:499-503

Phipps, R. H., J. D. Sutton, D. E. Beever, and A. K. Jones. 2000. The effect of crop maturity on the nutritional value of corn silage for lactating dairy cows. 3. Food intake and milk production. Anim. Sci. 71:401-409.

Phipps, R. H., J. D. Sutton, and B. A. Jones. 1995. Forage mixtures for dairy cows: the effect on dry-matter intake and milk production of incorporating either fermented or urea-treated whole crop wheat, brewers' grains, fodder beet or corn silage into diets based on grass silage. Anim. Sci. 61:491-496.

Porter, M. G., R. W. J. Steen, D. J. Kilpatrick, F. J. Gordon, C. S. Mayne, R. E. Poots, E. F. Unsworth, and C. J. Pippard. 1995. Electrometric titration as a method of predicting the chemical composition and corrected dry matter concentration of silage. Anim. Feed Sci. Technol. 56:217-230.

SAS Institute. 2005. User's Guide: Statistics. Version 9.1. SAS Inst., Cary, NC.

Sinclair, L. A., M. A. Jackson, J. A. Huntington, and R. J. Readman. 2005. The effects of processed, urea-treated whole-crop wheat or corn silage and supplementation of whole-crop wheat on the performance of dairy cows. Livest. Prod. Sci. 95:1-10.

Steen, R. W. J., F. J. Gordon, L. E. R. Dawson, R. S. Park, C. S. Mayne, R. E. Agnew, D. J. Kilpatrick, and M. G. Porter. 1998. Factors affecting the intake of grass silage by cattle and prediction of silage intake. Anim. Sci. 66:115-127.

Sutton, J. D., S. B. Cammell, D. E. Beever, D. J. Humphries, and R. H. Phipps. 1998. Energy and nitrogen balance of lactating dairy cows given mixtures of urea-treated whole crop wheat and grass silage. Anim. Sci. 67:203-212.

Sutton, J. D., R. H. Phipps, S. B. Cammell, and D. J. Humphries. 2001. Attempts to improve the utilization of urea-treated wholecrop wheat by lactating dairy cows. Anim. Sci. 73:137-147.

Tyrrell, H. F., and J. T. Reid. 1965. Prediction of the energy value of cows' milk. J. Dairy Sci. 48:1215-1233.

Vérité, R., and J. L. Peyraud. 1989. Protein: The PDI systems. Pages 33-47 in Ruminant Nutrition. Recommended allowances and feed tables. R. Jarrige, ed. John Libbey, Eurotext, Montrouge, France.

Vérité, R., S. Rétif, and P. Faverdin. 1996. Milk urea as an index for nutritive protein balance and urinary $\mathrm{N}$ excretion in dairy cows on conserved diets. EAAP Publ. 81:277. Eur. Assoc. Anim. Prod., Rome, Italy.

Whitaker, D. A., J. M. Kelly, and E. J. Smith. 1983. Subclinical ketosis and serum $\beta$-hydroxybutyrate levels in dairy cattle. Br. Vet. J. 139:462-463. 